\title{
The Effect of Boron, Calcium, and Surface Moisture on Shoulder Check, a Quality Defect in Fresh-market Tomato
}

\author{
Jin-Sheng Huang and S.S. Snapp ${ }^{1}$ \\ Department of Horticulture, Michigan State University, East Lansing, MI 48824-1325
}

\begin{abstract}
ADDITIONAL INDEX WORDS. micro-cracks, cuticle cracking, Lycopersicon esculentum, nutrition, fruit quality
AвSTRACт. The appearance of a fruit quality defect, shoulder check in fresh-market tomatoes (Lycopersicon esculentum Mill.), has devastated the Michigan industry, and caused sporadic concern elsewhere. The defect appears as a surface roughness that occurs primarily on the shoulder area of the fruit. The fruit appearance is damaged and storability is severely compromised. Microscopic inspection reveals that the surface roughness consists of many microscopic cracks that occur in parallel lines. Our objectives were to describe this defect and evaluate the role of weather conditions and fruit surface moisture in inducing it. Field experiments were conducted in 2001 and 2002 in Southwest Michigan, using the industry standard cultivar Mountain Spring and recommended practices for irrigated, staked fresh market production. The effects of fruit surface wetness and nutrition on quality were evaluated by comparing responses to a plastic rain shelter; Surround WP kaolin spray (to enhance surface wetness); a foliar spray of calcium (Ca at 2 g.L-1), boron (B at 300 mg. $\mathrm{L}^{-1}$ ), Ca plus B, water alone; and no treatment. A complementary greenhouse experiment investigated the effects of low and high rates of foliar sprays. A very consistent association was found between defect incidence and precipitation events that followed periods of hot, dry weather during rapid fruit expansion. Fruit quality was highest and incidence of defects least in fruit produced under plastic rain covers, with an average marketable yield of $62,270 \mathrm{vs} .44,340 \mathrm{~kg} \cdot \mathrm{ha}^{-1}$ for the control. A $28 \%$ reduction in defects was consistently associated with $\mathrm{Ca}+\mathrm{B}$ sprays across harvests and years. In contrast, $\mathbf{1 8 \%}$ more fruit had shoulder check defect with kaolin spray, a consistent increase in defect across years compared to control fruit. Greenhouse and field studies gave markedly similar results, except for a water spray control. Incidence of defect was consistently low with the highest rate of $B$ foliar spray.
\end{abstract}

In recent years fresh-market tomato growers in Michigan have experienced severe problems with a fruit defect variously referred to as shoulder defect, russeting or weather check. Losses to fresh-market tomato producers in the region have been as high as $80 \%$ for some harvests during the later part of the 1999 and 2000 growing seasons (Hausbeck et al., 2002). Appearance of the defect is quite variable and has been difficult to predict (Snapp et al., 2001). A general association with rapid changes in weather has been observed, usually when humid conditions or major rainfall follows an extended period of hot, dry weather (Huang et al., 2001). A similar defect has been observed in North Carolina fresh-market tomato production, where it is frequently referred to as rain check because of its association with precipitation after a hot, dry spell (D. Sanders, personal communication, 2001).

The defect is expressed within the epicarp and cuticular surface of the fruit, frequently appearing as a roughened section on areas that are rapidly expanding, such as on the fruit shoulder (Snapp et al., 2001). Storability of fruit is greatly reduced by shoulder check, and the blemish generally renders the fruit unmarketable. Pathogens are not thought to cause the symptoms associated with this disorder, nor has any relationship been found between defect severity and application of a wide array of fungicides (Hausbeck et al., 2002). A preliminary study indicated that shoulder check occurs in a wide range of tomato cultivars, particularly the widely grown fresh-market cultivar Mountain Spring (Snappetal., 2002). The industry urgently requires a better understanding of the anatomy of the defect, and management practices that could reduce its incidence.

Received for publication 24 Feb. 2003. Accepted for publication 25 Jan. 2004. This research was funded in part by a grant from Project GREEEN. Use of trade names does not imply endorsement by the Mich. Dept. of Agriculture of products named nor criticism of similar ones not mentioned. We gratefully acknowledge Frank Dennis for his helpful review and Syngenta Seeds, Inc., and Rupp Seeds, Inc. for providing seeds.

'Corresponding author; email snapp@msu.edu.
Mineral nutrition and water management are primary determinants of fruit quality in fresh-market tomatoes (Dorais et al., 2001). Conditions that are conducive to shoulder check appear to be similar to environments that enhance crack formation in tomato fruit (Huang et al., 2001). Rapid expansion of fruit and movement of solutes and water into fruit is generally associated with radial cracking (Peet, 1992). Application of excess irrigation water to greenhouse tomato systems induced two-fold higher incidence of radial cracking in fruit compared to recommended water regimes (Peet and Willits, 1995). A complex interaction of environment and genetics influence plant water and nutritional status, as well as tissue rigidity. Increasing Ca levels - even incrementally-in many vegetable tissues is associated with enhanced membrane stabilization, and lower internal defects (Shear, 1975). Addition of supplemental $\mathrm{Ca}$, or manipulation of $\mathrm{Ca}$ nutrition through pruning or water management, may prevent radial cracking of tomato fruit (Simon, 1978) or reduce cuticle cracking (Dorais et al., 2001; Ehret and Ho, 1986).

Studies in a range of plant species indicate that $\mathrm{Ca}$ interacts with $\mathrm{B}$, which has a stabilizing influence on $\mathrm{Ca}$ complexes in the middle lamella. Boron deficiency appears to induce hollow stem disorder in broccoli (Brassica oleracea L.) and stem crack in celery (Apium L.) (Shelp, 1993). In pear (Pyrus communis L.) fruit, preharvest application of $\mathrm{B}$ had long-term benefits, reducing postharvest defects associated with Ca deficiency such as brown heart (Xuan et al., 2001). In apple (Malus sylvestris var. domestica.) foliar application of B reduced Ca deficiency symptoms in the fruit (Dixon et al, 1973). Foliar and soil application of B reduced concentric and radial cracks in tomato fruit (Davis et al., 2003). The combination of $\mathrm{Ca}$ and $\mathrm{B}$ applied as a foliar spray reduced incidence (20\%) and severity (50\%) of cuticle cracking in tomato fruit (Dorais et al., 2001). 
Table 1. Treatments applied to tomato plants in 2001-02.

\begin{tabular}{|c|c|c|c|}
\hline \multirow[b]{2}{*}{ Treatment } & & \multicolumn{2}{|l|}{ Timing } \\
\hline & & 2001 & 2002 \\
\hline \multicolumn{4}{|l|}{ Field } \\
\hline \multicolumn{4}{|l|}{ Control $^{\mathrm{z}}$} \\
\hline Plastic cover & & Installed on 8 Aug. & Installed on 8 Aug. \\
\hline \multicolumn{2}{|l|}{ Foliar and fruit sprayy } & Applied on 10, 17, 24 Aug. & Applied on 24, 31 July; 7, 14, 21 Aug. \\
\hline & Surround kaolin (70 g.L $\left.\mathrm{L}^{-1}\right)$ & & \\
\hline & $\mathrm{Ca}\left(2 \mathrm{~g} \cdot \mathrm{L}^{-1}, 2002 \text { only }\right)^{\mathrm{x}}$ & & \\
\hline & $3\left(300 \mathrm{mg} \cdot \mathrm{L}^{-1}\right.$ from borax, 2002 only)w & & \\
\hline & $\mathrm{Ca}\left(2 \mathrm{~g} \cdot \mathrm{L}^{-1}\right)+\mathrm{B}\left(300 \mathrm{mg} \cdot \mathrm{L}^{-1}\right)$ & & \\
\hline & Water & & \\
\hline \multicolumn{4}{|l|}{ Greenhouse } \\
\hline \multicolumn{4}{|l|}{ Control } \\
\hline \multicolumn{2}{|l|}{ Foliar and fruit spray ${ }^{\mathrm{v}}$} & \multicolumn{2}{|c|}{ Weekly sprays started on 8 Aug. } \\
\hline \multicolumn{4}{|c|}{ Water } \\
\hline \multicolumn{4}{|c|}{ Low $\mathrm{Ca}\left(1 \mathrm{~g} \cdot \mathrm{L}^{-1}\right.$ from $\left.\mathrm{CaCl}_{2}\right)$} \\
\hline \multicolumn{4}{|c|}{ High $\mathrm{Ca}\left(2 \mathrm{~g} \cdot \mathrm{L}^{-1}\right.$ from $\left.\mathrm{CaCl}_{2}\right)$} \\
\hline \multicolumn{4}{|c|}{ Low B (150 mg.L $\mathrm{L}^{-1}$ from borax) } \\
\hline \multicolumn{4}{|c|}{ High B (300 mg.L $\mathrm{L}^{-1}$ from borax) } \\
\hline \multicolumn{4}{|c|}{$\mathrm{Ca}\left(2 \mathrm{~g} \cdot \mathrm{L}^{-1}\right)+\mathrm{B}\left(300 \mathrm{mg} \cdot \mathrm{L}^{-1}\right)$} \\
\hline & Surround kaolin $\left(70 \mathrm{~g} \cdot \mathrm{L}^{-1}\right)$ fruit spray & \multicolumn{2}{|c|}{ Weekly sprays started on 8 Aug. } \\
\hline
\end{tabular}

¿Conventional black plastic mulch.

y First application at green fruit stage.

${ }^{x} \mathrm{CaCl}_{2}$ was used for 2001, while FOLI-CAL ${ }^{\circledR}$ (10\% Ca chelated with mannitol) (Brandt Consolidated, Pleasant Plains, Ill. 62677) was used as calcium source for 2002.

wBorax $\left(13.35 \% \mathrm{~B}, \mathrm{Na}_{2} \mathrm{~B}_{4} \mathrm{O}_{7} .10 \mathrm{H}_{2} \mathrm{O}\right)$.

vFirst application when fruit were $20 \mathrm{~mm}$ in diameter.

A challenge to conducting B nutrition studies is that deficiency and toxicity levels are not far apart: B in soil solution at $8 \mathrm{mg} \cdot \mathrm{L}^{-1}$ reduced fruit weight and shoot growth in tomato, compared to B at $1.5 \mathrm{mg} \cdot \mathrm{L}^{-1}$ (Francois, 1984). Sandy, well drained soils are vulnerable to $\mathrm{B}$ deficiencies from leaching, and Michigan tomato production recommendations include a 1.12 to $3.36 \mathrm{~kg} \cdot \mathrm{ha}^{-1}$ application of $\mathrm{B}$ at planting in sandy soils (Vitosh et al., 1994). However, the rapidly expanding, large, round fruit such as fresh-market tomato may be vulnerable to B deficiencies even in B-amended soil (Snapp et al., 2002). A balance is required between fertigation strategies that support sufficient transport of $\mathrm{Ca}$ and $\mathrm{B}$ to the rapidly expanding fruit to maintain fruit quality, and variable or excess watering, which may exacerbate fruit cracking (Peet and Willits, 1995).

No clear relationship between fruit size and shoulder check incidence has been observed (J.Huang, unpublished data), although increased susceptibility to radial cracking has been found in jumbo sized fruit compared to moderate sized fruit (Considine and Brown 1981; Koske et al., 1980). Cuticle cracking was found to increase with increased fruit size (Emmons and Scott, 1998), but Bakker (1988) found the reverse relationship, and fruit size was not related to cuticle cracking in a study by Ehret et al.(1993). In a preliminary investigation of shoulder check defect, epidermal thickness as evaluated by microscopic examination of fixed surface tissue samples, did not appear to be related to defect severity (Snapp et al., 2002). Initial observations indicate that severe shoulder check occurred sporadically across ten different tomato varieties at a wide range of fruit ripeness stages, from mature green to ripe red. In contrast, cuticle cracking appeared to occur most commonly in tomato fruit at the mature green stage (Emmons and Scott 1997; Young, 1947).

Kamimura et al. (1972) showed that high soil moisture lowered the tensile strength of tomato fruit skin, resulting in rapid enlargement and formation of many minute cracks under wet conditions that later developed into visible ones. These cracks act as focal points for skin stresses, causing ruptures and cracking (Brown and Considine, 1982). However, our preliminary studies indicated that soil moisture status and macro-nutrient manipulation through fertigation treatments did not alter shoulder check incidence in fresh-market tomato cultivars (Snapp et al., 2001). Cultural management strategies that have addressed amelioration of cracks, such as shading, pruning and staking plants, were considered, but preliminary evidence suggested limited impact on shoulder check (Brown and Price 1934; Emmons and Scott, 1997; Hausbeck et al., 2002). The wide variation in response to management suggests a role for a complex interaction of fruit growth rate, fruit load and epidermis extensibility (Bakker, 1988; Emmons and Scott, 1998). Taken together, our preliminary studies indicated that fruit surface moisture changes and nutrition were promising avenues to quantify the causal factors underlying shoulder check, and allowed simultaneous study of cultural techniques that might be adopted by growers to address this devastating problem.

The objectives of our study were to 1) describe the quality defect 'shoulder check' in the fresh-market tomato cultivar Mountain Spring; 2) evaluate the role of weather conditions and fruit surface moisture in inducing shoulder check incidence; and 3) evaluate if foliar applications of $\mathrm{B}$ and $\mathrm{Ca}$ could reduce the incidence of the defect and enhance fruit quality.

\section{Materials and Methods}

\section{Field experiment}

The research trial was carried out at the Southwest Michigan Research and Extension Center (SWMREC) located near Benton Harbor in the primary Michigan fresh-market tomato production area at $42.08^{\circ}$ latitude and $-86.36^{\circ}$ longitude, altitude $220 \mathrm{~m}$ above sea level. The soil was a Oakville fine sand (Alfisol Hapludalf), 
$88.9 \%$ sand, $4.7 \%$ silt and $6.4 \%$ clay in the 0 to $25 \mathrm{~cm}$ topsoil, and $91.9 \%$ sand and $5.4 \%$ clay in the subsoil 25 to $75 \mathrm{~cm}$. Organic carbon levels varied across the site from 0.4 to $0.6 \%$ in the topsoil and $0.2 \%$ to $0.3 \%$ in the subsoil. Before planting, $0 \mathrm{~N}-0 \mathrm{P}-49.8 \mathrm{~K}$ ( $\mathrm{K}$ at $\left.134.5 \mathrm{~kg} \cdot \mathrm{ha}^{-1}\right), 21 \mathrm{~N}-0 \mathrm{P}-0 \mathrm{~K}\left(\mathrm{~N}\right.$ at $35.3 \mathrm{~kg} \cdot \mathrm{ha}^{-1}$ ), sulfur ( $\mathrm{S}$ at $\left.28 \mathrm{~kg} \cdot \mathrm{ha}^{-1}\right)$, and Solubor $(17.5 \% \mathrm{~B})\left(\mathrm{B}\right.$ rate at $\left.1 \mathrm{~kg} \cdot \mathrm{ha}^{-1}\right)$ were applied. Calcium fortified micronutrient blend was also applied at a rate of $112 \mathrm{~kg} \cdot \mathrm{ha}^{-1}$ with $\mathrm{Ca} 11.21 \mathrm{~kg}, \mathrm{Mg} 6.73 \mathrm{~kg}, \mathrm{~S} 5.6 \mathrm{Kg}, \mathrm{Zn}$ $3.36 \mathrm{~kg}, \mathrm{Fe} 2.24 \mathrm{~kg}, \mathrm{~B} 1.12 \mathrm{~kg}, \mathrm{Cu} 1.12 \mathrm{~kg}$, and Mn $1.12 \mathrm{~kg} \cdot \mathrm{ha}^{-1}$, respectively.

'Mountain Spring' tomato seeds were sown on 2 May 2001 and on 23 Apr. 2002 in a commercial greenhouse (Kietzer Farms, Inc., Hartford, Mich.) in 128-cell trays, and raised following recommended practices for transplants. Plants were transplanted with a $8 \mathrm{~N}-13.9 \mathrm{P}-4.2 \mathrm{~K}$ fertilizer solution to conventional raised, plasticmulched beds constructed using a commercial vegetable bed shaper ( $0.85 \mathrm{~m}$ in width and $0.15 \mathrm{~m}$ high) with drip irrigation on 8 June 2001 and 30 May 2002. The beds were fumigated with $187 \mathrm{~L} \cdot \mathrm{ha}^{-1}$ of Telone C-35 at the time of bed-shaping. Spacing was $0.46 \mathrm{~m}$ within row and $1.68 \mathrm{~m}$ between rows (13,037 plants/ha). Nutrients were applied through the drip system using $4 \mathrm{~N}-0 \mathrm{P}-6.6 \mathrm{~K}-2 \mathrm{Ca}(\mathrm{N}$ at $1.12 \mathrm{~kg} \cdot \mathrm{ha}^{-1} \cdot \mathrm{d}^{-1}$ ), starting $10 \mathrm{~d}$ after planting (18 June 2001 and 9 June in 2002). Plants were pruned to one sucker below the first flower cluster, staked and tied. Cultural management practices followed Michigan State Univ. (MSU) recommendations, including foliar applications of commercial fungicides (Asana, Bravo, Champ, Kelthan, and Thiodan) to prevent foliar bacterial and fungal disease.

Trial design was a randomized complete-block design, with four replications of each treatment. Treatments (Table 1) were applied to plots that consisted of two rows by $6 \mathrm{~m}$ (one $9 \mathrm{~m}$ row in 2002), for a total of 24 and 20 plants per treatment for 2001 and 2002, respectively. Treatments consisted of a control, plastic cover (6 mil thick, standard transparent plastic, stapled to irrigation pipe supports for surface coverage of the treatment rows); foliar spray of water, Surround WP (95\% kaolin) (Engelhard Co., Iselin, N.J.); $\mathrm{Ca}\left(2 \mathrm{~g} \cdot \mathrm{L}^{-1}\right)+\mathrm{B}\left(300 \mathrm{mg} \cdot \mathrm{L}^{-1}\right)$ and in 2002 , additional treatments of $\mathrm{Ca}\left(2 \mathrm{~g} \cdot \mathrm{L}^{-1}\right)$ and B $\left(300 \mathrm{mg} \cdot \mathrm{L}^{-1}\right)$ applied separately (Table 1$)$. Kaolin was applied per manufacture's recommendations at the rate of $70 \mathrm{~g} \cdot \mathrm{L}^{-1}$. Treatments were initiated on $8 \mathrm{Aug}$. 2001 and 24 July 2002, and applied weekly thereafter.

Four harvests were conducted from 7 Sept. to 24 Oct. 2001, and six harvests from 23 Aug. to 11 Oct. 2002. Six plants in each plot were monitored weekly until harvest and all fruit were evaluated for yield and quality determinations, where all fruit at pink stage (just after breaker stage) or at greater maturity were harvested each week, following commercial practice. All fruit were graded to size number one large fruit ( $\geq 66 \mathrm{~mm}$ in diameter) and small fruit $(<66$ $\mathrm{mm}$ in diameter), and cull. All fruit in each of the first two size group were sorted into three categories: 1) those without check; 2 ) those with check that covered $\leq 10 \%$ of the fruit surface area; and 3) $>10 \%$ of the surface area. Fruit number and weight were recorded for all categories. After harvesting, the fruit skin around stem end was washed, sampled and dried in the oven at $56{ }^{\circ} \mathrm{C}$ for 1 week, and then ground to pass a $1-\mathrm{mm}$ sieve for nutrient $(\mathrm{N}, \mathrm{P}$, $\mathrm{K}, \mathrm{Ca}, \mathrm{Mg}$, and B) analysis. Fruit tissue total $\mathrm{N}$ was analyzed using a Kjeldahl procedure (Fleck, 1974). Other nutrient elements were tested based on the guidelines of AOAC 975.03B(b)/985.01 (Horwitz, 2000). The ground samples were digested in a combination of nitric and perchloric acids, followed by determination of $\mathrm{P}$, $\mathrm{K}, \mathrm{Ca}, \mathrm{Mg}$, and $\mathrm{B}$ concentrations by inductively coupled plasmaemission spectrometry (ICP).
ENVIronMENTAL MONITORING. Watchdog weather station (Spectrum Technologies, Plainfield, Ill.) was used to monitor precipitation, soil and air temperature, and surface wetness (on a relative scale of dry 0 to wet 15 ) for control and plastic cover treatments.

CONFOCAL MiCroscopic OBSERVATION. Fruit with shoulder check defect were selected from field experiments to evaluate the anatomy of the defect, using confocal microscopic analysis. The epidermis specimens were cut from fresh fruit and were observed on a laser scanning confocal microscope (model 210; Carl Zeiss, Inc., Thornwood, N.Y.) using the 488 line of a dual line argon ion laser and an LP520 barrier filter. The same specimens were observed in conventional fluorescence, using a mercury bulb with a BP450-490 excitation filter and a LP520 barrier filter.

\section{Greenhouse experiment}

Fresh-market tomato transplants were started as described for the field experiment in 2001, and transported to a greenhouse at the MSU campus in East Lansing. Plants were transplanted into 11.35-L pots filled with BACCTO High Porosity Professional planting mix (Michigan Peat Co., Houston, Texas) with preplant nutrients incorporated in and limed to $\mathrm{pH} 5.5$ to 6.5 on 12 June 2001. Nutrient solutions were applied through the irrigation system 2 weeks after transplanting with commercial MSU special fertilizer (19N-1.8P-19.1K-2Ca plus micronutrients) (GreenCare Fertilizer, Chicago, Ill.). Nitrogen was applied at $100 \mathrm{mg} \cdot \mathrm{L}^{-1}$ each irrigation with a ratio of $1 \mathrm{~N}: 1 \mathrm{~K}$. The ratio of $\mathrm{N}$ : $\mathrm{K}$ was then changed to 1 : 2 at the stage of fruit set with extra $\mathrm{K}$ added in the nutrient solutions as $\mathrm{K}_{2} \mathrm{SO}_{4}$. Greenhouse temperature was set to $25^{\circ} \mathrm{C}$ at day and $20{ }^{\circ} \mathrm{C}$ at night.

A randomized complete-block design was used, with four plants in each block, and four replications. Treatments consisted of: control; foliar and fruit spray of water, $\mathrm{Ca}, \mathrm{B}$, and $\mathrm{Ca}+\mathrm{B}$; and kaolin fruit spray (Table 1). Weekly sprays were started $20 \mathrm{~d}$ after fruit set. Fruit defect was induced in the greenhouse by applying an overhead water spray twice in the evening before each harvest. Fruit were harvested each week just after breaker stage (pink stage). Number one large fruit ( $\geq 66 \mathrm{~mm}$ diameter) were recorded as yield and sorted into three categories, those without check, those with check that covered $\leq 10 \%$ of fruit surface area, and those with check that covered $>10 \%$ of fruit area. Fruit number and weight were recorded for all categories. After harvesting, a randomly selected group of fruit was used for nutrient analysis. The fruit skin around stem end was washed, sampled, dried, grounded, and analyzed for tissue content as described previously.

Statistical analysis. All data were subjected to analysis of variance across the year, by year (field experiments only) and date. Treatment effects were evaluated on final yield, fruit numbers and on an individual harvest basis. Means were separated by least significant differences (LSD) using SAS (SAS Institute, Cary, N.C.). PROC GLM and PROC REG were used to analyze the effect of leaf wetness on tomato fruit shoulder check incidence.

\section{Results and Discussion}

Anatomy of Shoulder CHEck. To the best of our knowledge this is the first report that describes the shoulder check defect of tomato in detail. A distinguishing feature of shoulder check was multiple micro-cracks oriented parallel to each other; this occurred across a range of fruit maturities from mature green to red stage (Figs. 1 and 2). Confocal microscopic examination of the rough, corky area revealed micro-cracks lined by fluoresced cells (Fig. 3 ). Fluoresced cells are often necrotic, as the yellow fluorescence 


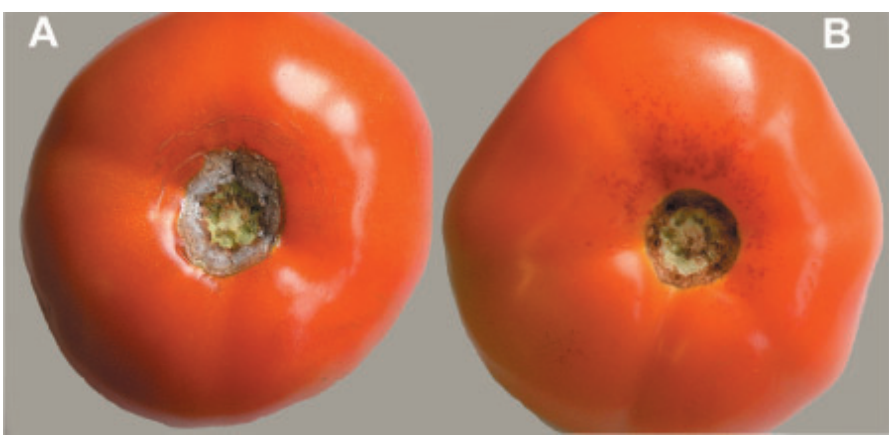

Fig. 1. Symptoms of tomato shoulder check defect. (A) Minor concentric cracks occur in field-grown tomatoes. (B) Russseting occurs in both field and greenhouse-grown tomatoes.


Fig. 3. Confocal fluorescence single optical section of fruit skin with micro-crack defect. Observation was made in conventional fluorescence, using a mercury bulb with a BP450-490 excitation filter and a LP520 barrier filter, showed that the light areas were fluorescing yellow. The arrows showed the micro cuticle cracks lined by the intact necrosis cells (light areas). (A) A line of cuticle crack with intact epidermal cell below. (B) A minor crack penetrated deeper into the epidermis.

is indicative of the presence of phenolics, the production of which is a common plant response to injury or infection (J.H. Whallon, personal communication). These were generally no wider than 1 $\mathrm{mm}$, although some were visible with the unaided eye and were up to $50 \mathrm{~mm}$ long (data not shown). Minor concentric cracks that penetrated the cuticle or deeper into the epidermis frequently occurred in combination with a russeting pattern of parallel, necrotic cells on the fruit surface (Fig. 1A). Russeting was the primary evidence of shoulder check in greenhouse-grown fruit (Fig. 1B).

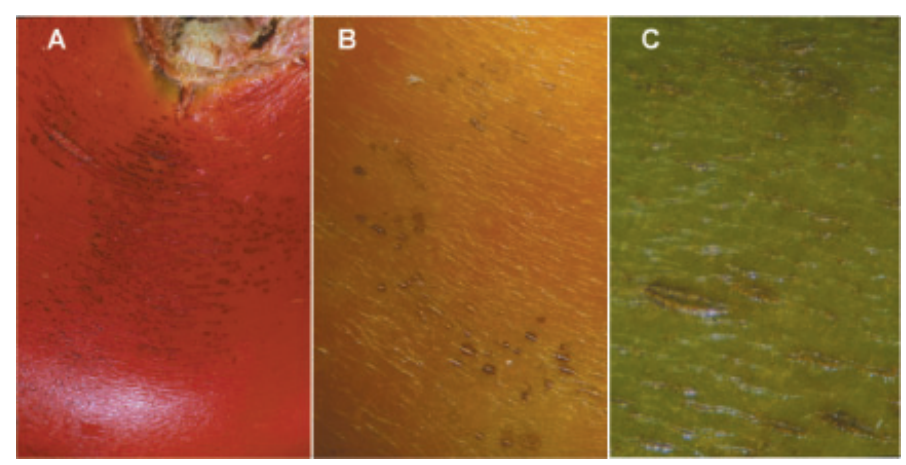

Fig. 2. Tomato fruit shoulder check defect occurs at pink (A), breaker (B), and mature green $(\mathbf{C})$ stages (Common, 2000).

A type of surface roughness similar to shoulder check is associated with cuticle cracking; this has been referred to as russeting (Emmons and Scott, 1998; Young, 1947). However, cuticle cracking consists of very fine, randomly orientated cracks that form a network all over the fruit surface (Bakker, 1988). Cuticle cracking is almost entirely confined to the surface of the epidermis, whereas shoulder check frequently penetrates the epidermis and is concentrated in the shoulder area of the fruit. Radial cracks or tears in tomato fruit also differ from shoulder check, both in orientation, and in size. Radial cracks are almost always visible to the unaided eye and penetrate deeply into the epidermis, frequently extending through the outer pericarp.

Cracks and splits in tomato fruit, both radial and concentric in form, have been described in the literature for many years (Brown and Price, 1934; Frazier, 1934). Cuticle cracking was first described by Young in 1947. The causes of fruit cracking are not clearly defined, although precipitation events or irrigation can exacerbate different forms of cracking, through either a sudden or chronic tension on the surface of the fruit brought about by water uptake (Hayman, 1987; Peet, 1992). Absorption of external moisture by minute cracks, corky spots, or the corky layer around the stem was one of the main factors associated with cracking in early research (Frazier, 1934). Similar causes may underlie shoulder check incidence.

ENVIRONMENTAL CONDITIONS AND SHOULDER CHECK OCCURRENCE. The 10-year average for heat accumulation at SWMREC over a tomato growing season (1 June to 15 Oct.) is 1315 degree days, base $10^{\circ} \mathrm{C}$. Degree-day accumulation at SWMREC was 1263 in 2001, and 1481 in 2002, indicating a slightly cooler and warmer than normal year, respectively. Recently, growers have noted that a 2-week dry spell generally occurs in late July, when the temperature is typically $>30^{\circ} \mathrm{C}$. This is a critical fruit expansion period, and onset of shoulder check has been observed within $48 \mathrm{~h}$ of the first rainfall after this dry spell, generally in early August (M. Hausbeck, unpublished, 2001). Fig. 4A shows leaf wetness for plants from the 2001 field experiment with and without a plastic rain shield where only trace amount of precipitation occurred from 11 July to 31 July. A similar pattern was observed in 2002 (Fig. 4B).

In concurrence with grower observations, the onset of shoulder check in both 2001 and 2002 occurred during the late August to early September period (Fig. 5A-D) when the fruit was rapidly expanding and significant rainfall occurred. Shoulder check was observable at and after mature green stage (Fig. 2). Interestingly, the incidence of shoulder check was first shown during the period that leaf wetness hours rose sharply in the control, at about the week of 15 Aug. in 2001 and 2002. Weekly cumulative hours of leaf wetness were significantly higher in control plants than in plastic cover treatment plants (Fig. 4). As a result, the minimal 
levels of shoulder check was observed on fruit protected from precipitation by a plastic cover $\left(1910 \mathrm{~kg} \cdot \mathrm{ha}^{-1}\right.$ of fruit with bigger than $10 \%$ check in protected plants vs. $7610 \mathrm{~kg} \cdot \mathrm{ha}^{-1}$ in control plants; means of 2-year yield from Table 2). Plastic cover treatment also consistently showed the highest percentage of marketable yield for both 2001 and 2002 season (Table 2). The average mean air temperature was not affected by plastic covers in either growing season (data not shown). Installation of the rain shield across the top of the plant canopy with sides exposed to air movement, minimized temperature effects.

To investigate the effect of leaf wetness hours on tomato shoulder check incidence, the response of percent defected yield to the cumulative leaf wetness hours in the early period (from 15 Aug. to 4 Sept.) and entire fruit harvest period (from 15 Aug. to 2 Oct.) was analyzed (Table 3 ). Tomato shoulder check incidence ( $\leq 10 \%$ defect, $>10 \%$ defect and total defect) was significantly and positively correlated to leaf wetness. Based on LSD analysis, leaf wetness hours in Table 3 could be categorized into two groups, high leaf wetness $(65,71$, 159 , and 234) and low leaf wetness $(6,18,20$, and 31). High wetness hours had significantly high percent defect yield, whereas low wetness hours were related to less defect incidence (Table 3).

Cultural management in the field ENVIRONMENT. Overall the yield of fruit was much higher in 2002, primarily because of an earlier planting date (Fig. 4). The interactive effects of year and treatment on yield were not significant. Total fruit yield was not affected by treatment in the field experiment (data not shown), whereas yield of marketable fruit that met US No. 1 size requirements with no discernible shoulder defect was influenced by cultural treatments (Table 2). The yield of unblemished, marketable No. 1 fruit was significantly higher in the plastic cover treatment for both years and in $\mathrm{Ca}+\mathrm{B}$ treatment in 2001, compared to the conventional production practice control (Table 2). The $\mathrm{Ca}+$ $\mathrm{B}$ treatment showed the trends in increasing the marketable yield in 2002. Ca and B sprays alone significantly increased the percent marketable yield in 2002 (Table 2 ). In comparison with water spray treatment, $\mathrm{Ca}+\mathrm{B}$ treatment also significantly increased percent marketable yield and reduced percent $\leq 10 \%$ defect yield in 2001. $\mathrm{Ca}, \mathrm{B}$, and $\mathrm{Ca}+\mathrm{B}$ treatments showed consistent trends towards increased marketable yield and reduced tomato shoulder check incidence in 2002, compared to water treatment (Table 2). Fruit number, fruit weight and the percentage of total yield responded in a similar manner to treatments (Fig. 5, Table 2). In both years, treatment effects were markedly consistent across harvests.

Fruit surface moisture varied from relatively dry (plastic cover) to moderately wet (control) to excessively wet (Surround kaolin foliar spray). Kaolin a hydroscopic clay, induced the formation and retention of a water film on fruit and leaves (data not shown). Further, the white kaolin spray reflected heat, for a cooler fruit and vegetative surface that induced water droplet formation at the fruit surface and on nearby leaves. Kaolin-sprayed grapefruit (Citrus $\times$ paradisi Macfad. (pro sp.) [maxima $\times$ sinensis]) leaves had relatively low surface temperature (Jifon and Syvertsen, 2003), which tended to enhance the extent of surface wetness, and drying time. The plastic cover treatment had the lowest levels of defect in both years, whereas the kaolin treatment consistently increased defect $10.4 \%$ to $20.1 \%$ compared to the control, for the $>10 \%$ defect category (Table 2 ). Taken together, the data indicate that fruit surface moisture could be associated with increased severity of shoulder check defect.

Another explanation for increased susceptibility of kaolin-treated fruit to shoulder check is that kaolin clay may increase fruit water permeability by enhancing tomato fruit cuticle transpiration (Nakano and Uehara, 1996). Nakano and Uehara (1996) suggest that kaolin powder may combine with the wax layer to increase water movement through the epidermis. Kaolin-treated fruit could adsorb

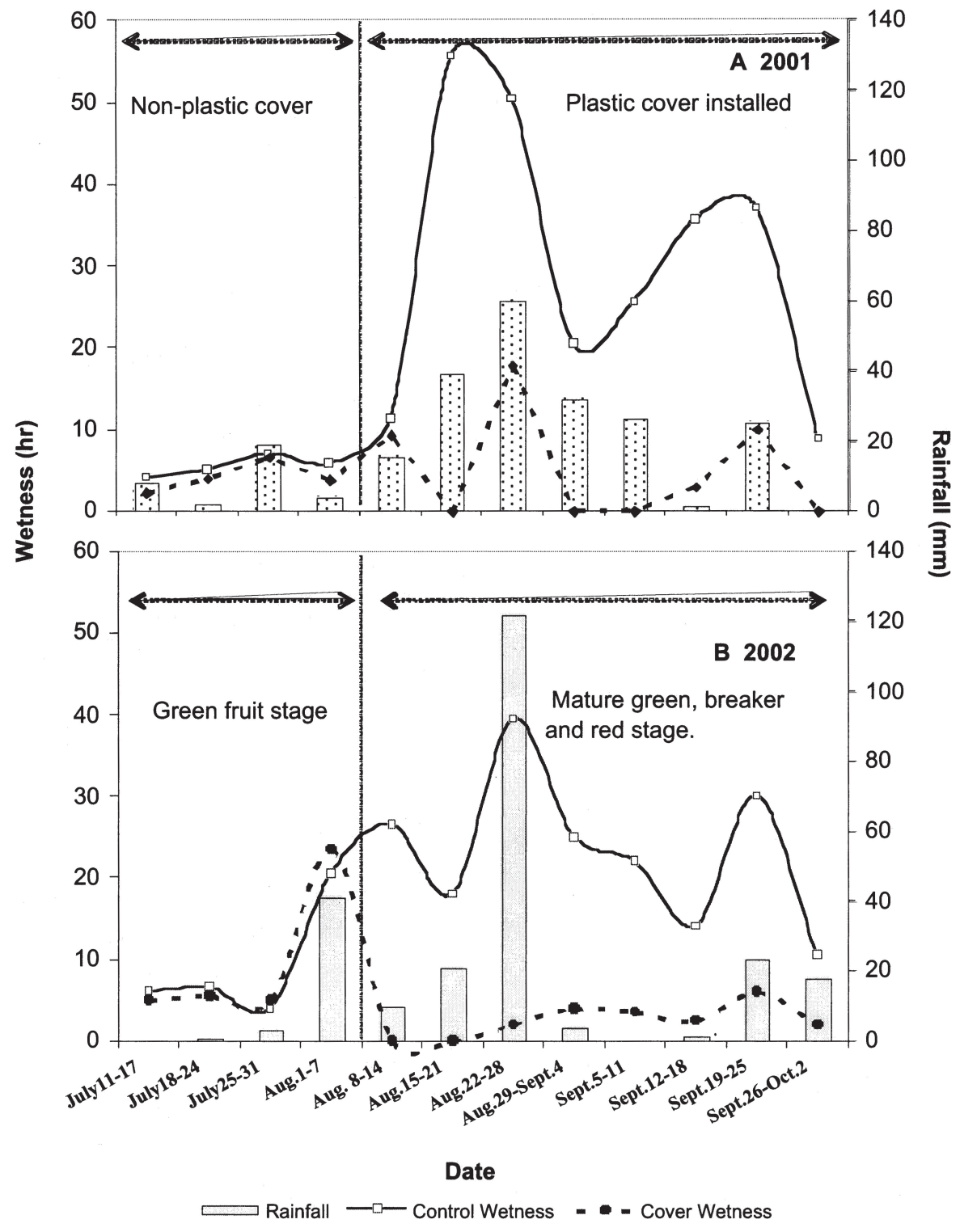

Fig. 4. Weekly cumulative rainfall and leaf wetness hours of control and plastic cover treatments during 2001 and 2002 growing season. Plastic cover was installed on 8 Aug. 2001 and 2002. Leaf wetness hours are defined as the cumulative hours when leaf wetness reading is bigger than or equal to threshold.; leaf wetness threshold $=12$. 

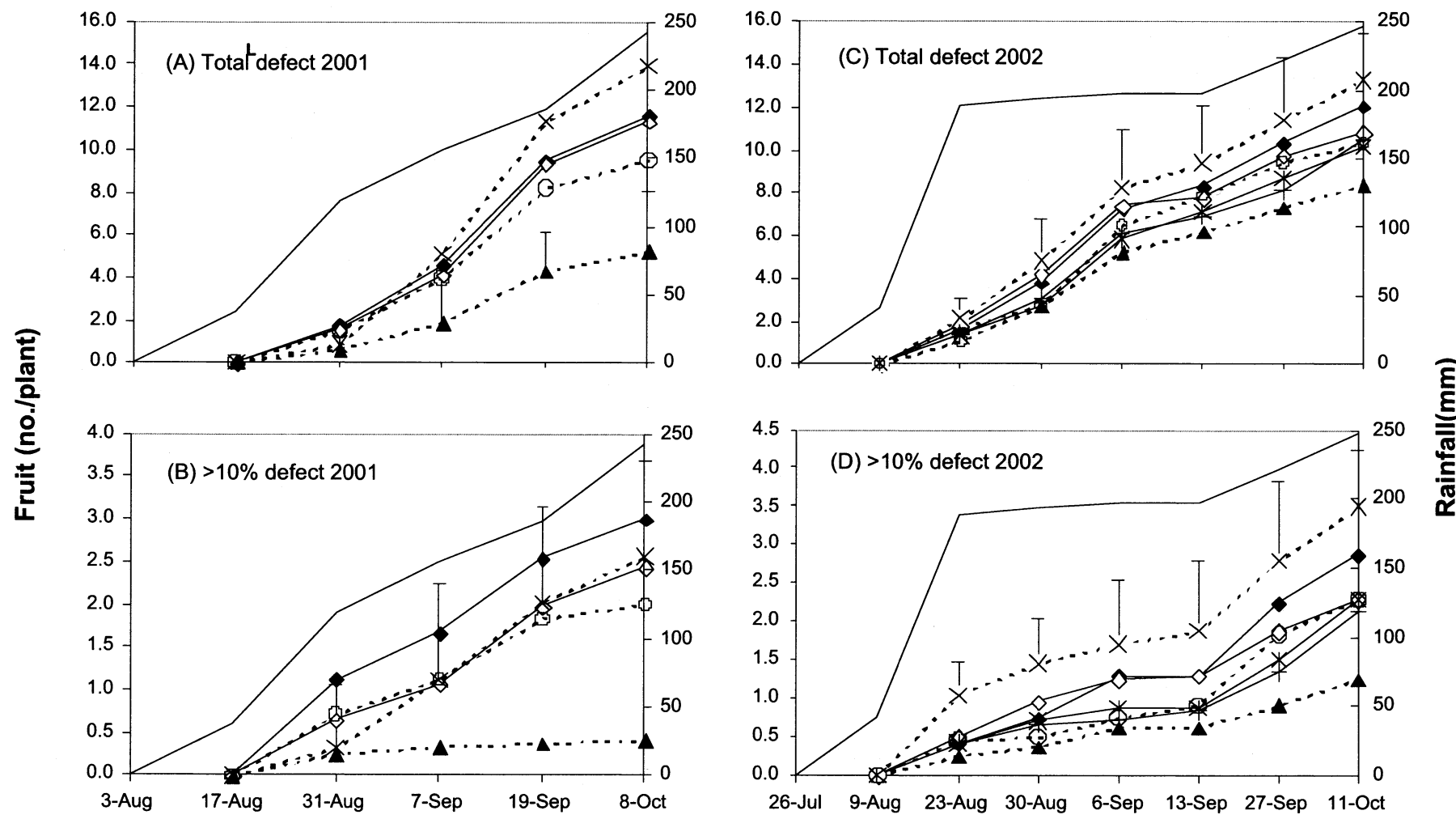

Harvest date

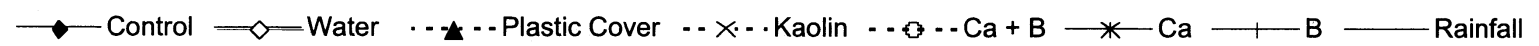

Fig. 5. Cumulative precipitation in 2001 and 2002 (right Y axis) and cumulative effects of treatments on number of fruit with shoulder check defect in field-grown tomatoes. The vertical bars represent $\mathrm{LSD}_{0.05}$ for each harvest.

Table 2. Cumulative yield and the percentage of total yield are presented for different market classes of fresh-market tomatoes: marketable fruit (no defects), $\leq 10 \%$ and $>10 \%$ shoulder check defect. Treatments initiated at early fruit set in field experiments at SWMREC. NA $=$ not applicable as this treatment was not applied in 2001. Control = no treatment applied; water $=$ sprayed with same amount of water applied with calcium and boron foliar sprays; kaolin $=$ sprayed with Surround kaolin at $70 \mathrm{~g} \cdot \mathrm{L}^{-1}$; cover $=$ plastic rain cover installed; Ca $+\mathrm{B}=$ foliar spray with both calcium at $2 \mathrm{~g} \cdot \mathrm{L}^{-1}+$ boron at $300 \mathrm{mg} \cdot \mathrm{L}^{-1} ; \mathrm{Ca}=$ foliar spray with calcium at $2 \mathrm{~g} \cdot \mathrm{L}^{-1} ; \mathrm{B}=$ foliar spray with boron at $300 \mathrm{~m} \cdot \mathrm{L}^{-1}$.

\begin{tabular}{|c|c|c|c|c|c|c|}
\hline \multirow[b]{2}{*}{ Treatment } & \multicolumn{3}{|c|}{2001} & \multicolumn{3}{|c|}{2002} \\
\hline & Marketablez $^{z}$ & $\leq 10 \%$ Defect & $>10 \%$ Defect & Marketable & $\leq 10 \%$ defect & $>10 \%$ defect \\
\hline \multicolumn{7}{|c|}{ Yield $\left(\mathrm{kg} \cdot \mathrm{ha}^{-1}\right)$} \\
\hline Control & $34,015 \mathrm{~cd} y$ & $27,307 \mathrm{~b}$ & $6,285 \mathrm{a}$ & $54,671 \mathrm{~b}$ & 31,072 & $8,938 \mathrm{ab}$ \\
\hline Water & $36,349 \mathrm{bc}$ & $29,121 \mathrm{~b}$ & $5,712 \mathrm{a}$ & $62,181 \mathrm{ab}$ & 28,035 & $6,695 \mathrm{abc}$ \\
\hline Cover & $49,622 \mathrm{a}$ & $15,476 \mathrm{c}$ & $580 \mathrm{~b}$ & 74,913 a & 22,589 & $3,243 \mathrm{~d}$ \\
\hline Kaolin & $27,181 \mathrm{~d}$ & 39,347 a & $7,548 \mathrm{a}$ & $60,416 \mathrm{ab}$ & 30,184 & $9,864 \mathrm{a}$ \\
\hline $\mathrm{Ca}+\mathrm{B}$ & $43,209 a b$ & $23,941 \mathrm{~b}$ & $4,552 \mathrm{a}$ & $68,422 \mathrm{ab}$ & 26,121 & $6,409 \mathrm{bcd}$ \\
\hline $\mathrm{Ca}$ & NA & NA & NA & $66,082 \mathrm{ab}$ & 23,910 & $6,163 \mathrm{bcd}$ \\
\hline B & NA & NA & NA & $68,153 \mathrm{ab}$ & 25,701 & $5,427 \mathrm{~cd}$ \\
\hline $\mathrm{LSD}_{0.05}$ & 7,680 & 5,836 & 3,739 & 17,396 & NS & 3,414 \\
\hline \multicolumn{7}{|c|}{ Percentage of total yield $(\%)$} \\
\hline Control & $50.6 \mathrm{c}$ & $40.3 \mathrm{~b}$ & $9.1 \mathrm{a}$ & $57.2 \mathrm{c}$ & $33.1 \mathrm{a}$ & $9.7 \mathrm{a}$ \\
\hline Water & $50.9 \mathrm{c}$ & $40.0 \mathrm{~b}$ & $8.1 \mathrm{a}$ & $63.9 \mathrm{abc}$ & $29.2 \mathrm{ab}$ & $6.9 \mathrm{ab}$ \\
\hline Cover & $75.4 \mathrm{a}$ & $23.7 \mathrm{~d}$ & $0.8 \mathrm{~b}$ & $74.1 \mathrm{a}$ & $22.6 \mathrm{~b}$ & $3.3 \mathrm{~b}$ \\
\hline Kaolin & $36.3 \mathrm{~d}$ & $53.6 \mathrm{a}$ & $10.1 \mathrm{a}$ & $60.1 \mathrm{bc}$ & $30.1 \mathrm{ab}$ & $9.9 \mathrm{a}$ \\
\hline $\mathrm{Ca}+\mathrm{B}$ & $60.7 \mathrm{~b}$ & $33.0 \mathrm{c}$ & $6.3 \mathrm{a}$ & $67.3 \mathrm{abc}$ & $26.1 \mathrm{ab}$ & $6.5 \mathrm{ab}$ \\
\hline $\mathrm{Ca}$ & NA & NA & NA & $68.7 \mathrm{ab}$ & $24.9 \mathrm{ab}$ & $6.5 \mathrm{ab}$ \\
\hline B & NA & NA & NA & $68.8 \mathrm{ab}$ & $25.8 \mathrm{ab}$ & $5.4 \mathrm{~b}$ \\
\hline $\mathrm{LSD}_{0.05}$ & 7.7 & 5.8 & 4.6 & 11.4 & 9.2 & 3.7 \\
\hline
\end{tabular}

${ }^{\mathrm{z}}$ No. 1 large ( $\geq 66 \mathrm{~mm}$ in diameter) fruit without defect.

y Mean separation within columns by LSD, $P \leq 0.05$.

ss Nonsignificant at $P \leq 0.05$. 
Table 3. For the early and entire fruit harvest periods $(15$ Aug. to 4 Sept. $=$ early and 15 Aug. to 2 Oct. $=$ entire $)$ we present the relationship between leaf wetness hours and tomato shoulder check incidence for the 2-year field experiments.

\begin{tabular}{|c|c|c|c|c|c|c|c|}
\hline \multirow[b]{2}{*}{ Year } & \multicolumn{3}{|c|}{ Wetness } & \multicolumn{4}{|c|}{ Percentage of total yield } \\
\hline & Period & (h) & Treatment & $\leq 10 \%$ Defect & $>10 \%$ Defect & Total defect & Nondefect \\
\hline 2001 & 15 Aug.-4 Sept. & 71 & Control & $35.92 \mathrm{a}^{\mathrm{z}}$ & $6.61 \mathrm{ab}$ & $42.53 \mathrm{ab}$ & $57.47 \mathrm{~cd}$ \\
\hline 2001 & 15 Aug.-4 Sept. & 18 & Plastic cover & $16.88 \mathrm{~b}$ & $0.89 \mathrm{c}$ & $17.77 \mathrm{~d}$ & $82.23 \mathrm{a}$ \\
\hline 2002 & 15 Aug.-4 Sept. & 65 & Control & $32.89 \mathrm{a}$ & $7.20 \mathrm{ab}$ & $40.10 \mathrm{~b}$ & $59.90 \mathrm{c}$ \\
\hline 2002 & 15 Aug.-4 Sept. & 6 & Plastic cover & $20.62 \mathrm{~b}$ & $2.41 \mathrm{bc}$ & $23.04 \mathrm{~cd}$ & $76.96 \mathrm{ab}$ \\
\hline 2001 & 15 Aug.-2 Oct. & 234 & Control & $40.27 \mathrm{a}$ & $9.10 \mathrm{a}$ & $49.37 \mathrm{a}$ & $50.63 \mathrm{~d}$ \\
\hline 2001 & 15 Aug.-2 Oct. & 31 & Plastic cover & $23.74 \mathrm{~b}$ & $0.84 \mathrm{c}$ & $24.57 \mathrm{~cd}$ & $75.43 \mathrm{ab}$ \\
\hline 2002 & 15 Aug.-2 Oct. & 159 & Control & $33.12 \mathrm{a}$ & $9.68 \mathrm{a}$ & $42.80 \mathrm{ab}$ & $57.20 \mathrm{~cd}$ \\
\hline \multirow[t]{2}{*}{2002} & 15 Aug.-2 Oct. & 20 & Plastic cover & $22.57 \mathrm{~b}$ & $3.30 \mathrm{bc}$ & $25.86 \mathrm{c}$ & $74.14 \mathrm{~b}$ \\
\hline & & & $\mathrm{LSD}_{0.05}$ & 7.39 & 5.14 & 6.86 & 6.86 \\
\hline \multicolumn{8}{|c|}{ Regression analyses } \\
\hline \multicolumn{8}{|c|}{ Significant linear fit } \\
\hline \multicolumn{8}{|c|}{ Nondefect $(\%)=76.11-0.124 \times$ wetness $; p<0.0001 ; R^{2}=0.652$} \\
\hline \multicolumn{8}{|c|}{$\leq 10 \%$ Defect $(\%)=21.72+0.087 \times$ wetness $; p<0.0001 ; R^{2}=0.539$} \\
\hline \multicolumn{8}{|c|}{$>10 \%$ Defect $(\%)=2.17+0.038 \times$ wetness $; p=0.0002 ; R^{2}=0.383$} \\
\hline \multicolumn{8}{|c|}{ Total defect $(\%)=23.89+0.124 \times$ wetness; $p<0.0001 ; R^{2}=0.652$} \\
\hline \multicolumn{8}{|c|}{ Significant quadratic fit } \\
\hline \multicolumn{8}{|c|}{ Nondefect $(\%)=81.67-0.331 \times$ wetness $+0.00024 \times$ wetness $\times$ wetness $; p<0.0001 ; R^{2}=0.764$} \\
\hline \multicolumn{8}{|c|}{$\leq 10 \%$ Defect $(\%)=18.02+0.224 \times$ wetness $-0.00059 \times$ wetness $\times$ wetness; $p<0.0001 ; R^{2}=0.624$} \\
\hline \multicolumn{8}{|c|}{$>10 \%$ Defect $(\%)=0.31+0.107 \times$ wetness $-0.00029 \times$ wetness $\times$ wetness; $p<0.0001 ; R^{2}=0.464$} \\
\hline \multicolumn{8}{|c|}{ Total Defect $(\%)=18.33+0.331 \times$ wetness $-0.00024 \times$ wetness $\times$ wetness; $p<0.0001 ; R^{2}=0.764$} \\
\hline
\end{tabular}

${ }^{\mathrm{z}}$ Mean separation within columns by LSD, $P \leq 0.05$.

Table 4. Fruit tissue analysis at tomato fruit shoulder area.

\begin{tabular}{|c|c|c|c|c|c|c|}
\hline \multirow[b]{2}{*}{ Treatment } & $\mathrm{N}$ & $\mathrm{P}$ & $\mathrm{K}$ & $\mathrm{Ca}$ & $\mathrm{Mg}$ & \multirow{2}{*}{$\begin{array}{c}\text { Boron } \\
\left(\mathrm{mg} \cdot \mathrm{kg}^{-1}\right)\end{array}$} \\
\hline & \multicolumn{5}{|c|}{$(\%)$} & \\
\hline \multicolumn{7}{|l|}{ Field 2001} \\
\hline Control & 3.21 & 0.94 & 8.02 & 0.39 & 0.34 & 22.0 \\
\hline $\mathrm{Ca}+\mathrm{B}$ spray & 2.89 & 0.69 & 5.71 & 0.26 & 0.24 & 28.2 \\
\hline $\mathrm{LSD}_{0.05}$ & 0.30 & 0.15 & 1.17 & 0.07 & 0.05 & 5.8 \\
\hline \multicolumn{7}{|l|}{ Field 2002} \\
\hline Control & 3.16 & 0.40 & 4.20 & 0.28 & 0.23 & 28.67 \\
\hline $\mathrm{Ca}+\mathrm{B}$ spray & 3.40 & 0.48 & 4.76 & 0.28 & 0.28 & 34.43 \\
\hline $\mathrm{LSD}_{0.05}$ & NS & NS & NS & NS & NS & 4.03 \\
\hline \multicolumn{7}{|l|}{ Greenhouse 2001} \\
\hline Water & $2.25 \mathrm{a}^{\mathrm{z}}$ & $0.64 \mathrm{a}$ & 5.40 & $0.26 \mathrm{~b}$ & $0.22 \mathrm{a}$ & $16.7 \mathrm{~b}$ \\
\hline Boron spray & $1.88 \mathrm{~b}$ & $0.58 \mathrm{c}$ & 5.39 & $0.25 \mathrm{~b}$ & $0.19 \mathrm{~b}$ & $49.0 \mathrm{a}$ \\
\hline Ca spray & $1.99 \mathrm{~b}$ & $0.59 \mathrm{bc}$ & 3.75 & $0.31 \mathrm{a}$ & $0.23 \mathrm{a}$ & $18.7 \mathrm{~b}$ \\
\hline $\mathrm{Ca}+\mathrm{B}$ spray & $1.95 \mathrm{~b}$ & $0.63 \mathrm{ab}$ & 5.75 & $0.30 \mathrm{a}$ & $0.20 \mathrm{~b}$ & $50.7 \mathrm{a}$ \\
\hline Surround & $2.23 \mathrm{a}$ & $0.65 \mathrm{a}$ & 5.49 & $0.24 \mathrm{~b}$ & $0.20 \mathrm{ab}$ & $17.3 \mathrm{~b}$ \\
\hline $\mathrm{LSD}_{0.05}$ & 0.13 & 0.05 & NS & 0.03 & 0.03 & 4.4 \\
\hline
\end{tabular}

${ }^{z}$ Mean separation within columns by LSD, $P \leq 0.05$.

NsNonsignificant at $P \leq 0.05$.

greater amounts of water from a precipitation event compared to control fruit, and this could induce higher rates of micro-cracks.

Foliar nutrient sprays were applied to alter tissue Ca and B status; with the expectation that nutrient sprays may also influence osmotic potential at the fruit surface. Application of a weekly foliar and fruit B and Ca spray at the fruiting stage reduced the incidence of shoulder check defect, at almost every harvest in both years (Table 2, Fig. 5). Monitoring of tissue nutrition indicated that foliar sprays had limited effect on Ca content at the fruit shoulder, whereas B content was increased from 22 to $28 \mathrm{mg} \cdot \mathrm{kg}^{-1}$ in 2001 , and from 29 to $34 \mathrm{mg} \cdot \mathrm{kg}^{-1}$ in 2002 for $\mathrm{Ca}+\mathrm{B}$ spray treatment (Table 4 ). Tomato fruit $\mathrm{B}$ content in a B deficient loamy sand soil has been reported as $17.1 \mathrm{mg} \cdot \mathrm{kg}^{-1}$ (Davis et al., 2003). Although B was applied to the entire field at transplanting, following recommended practice, it appears that soil application of B did not address B nutrition adequately in this sandy soil. In 2002, a B foliar spray was associated with reduced yield of fruit with $>10 \%$ shoulder check defect, compared to the control treatment. The same trend was observed for $\mathrm{Ca}+\mathrm{B}$ and for $\mathrm{Ca}$ alone (Table 2). Foliar application of B may be useful to enhance B levels in rapidly expanding fruit. Using foliar sprays to enhancing $\mathrm{Ca}$ status of fruit appears to be more problematic, which is not surprising, given the relative immobility and unavailability of Ca (Palta, 1996). The osmotic potential of the Ca spray may play a role in reducing incidence of tomato shoulder check, as it does in preventing crack formation in cherry (Prunus avium L.) fruit (Fernandez and Flore, 1998), but this was not tested in our study.

A weekly foliar spray of water was applied at the same rate as the 
Table 5. Average cumulative yield of tomato fruit in three fruit classes at East Lansing, Mich., in 2001. Treatments initiated at early fruit set in the greenhouse.

\begin{tabular}{|c|c|c|c|c|}
\hline \multirow[b]{2}{*}{ Treatment } & \multicolumn{4}{|c|}{ Yield (g/plant) } \\
\hline & Marketablez & $\begin{array}{l}\leq 10 \% \\
\text { defect }\end{array}$ & $\begin{array}{l}>10 \% \\
\text { defect }\end{array}$ & $\begin{array}{c}\text { Total } \\
\text { defect } \\
\text { yield }\end{array}$ \\
\hline$\overline{\text { Control }}$ & $866.61 \mathrm{ab}^{y}$ & $493.02 \mathrm{ab}$ & 130.33 & $623.35 \mathrm{abc}$ \\
\hline Water & $709.46 \mathrm{ab}$ & $537.50 \mathrm{ab}$ & 158.77 & $696.27 \mathrm{ab}$ \\
\hline Kaolin & $542.58 \mathrm{~b}$ & $573.57 \mathrm{a}$ & 166.46 & $740.03 \mathrm{a}$ \\
\hline High Ca & $974.63 \mathrm{a}$ & $408.64 \mathrm{abc}$ & 127.62 & $536.26 \mathrm{bcd}$ \\
\hline High B & $943.47 \mathrm{a}$ & $285.86 \mathrm{c}$ & 72.32 & $358.19 \mathrm{~d}$ \\
\hline Low $\mathrm{Ca}$ & $983.13 \mathrm{a}$ & $544.52 \mathrm{ab}$ & 112.95 & $657.47 \mathrm{abc}$ \\
\hline Low B & $931.53 \mathrm{a}$ & $443.57 \mathrm{abc}$ & 126.02 & $569.59 \mathrm{abc}$ \\
\hline $\mathrm{Ca}+\mathrm{B}$ & $1,008.97 \mathrm{a}$ & $393.21 \mathrm{bc}$ & 94.22 & $487.43 \mathrm{~cd}$ \\
\hline $\mathrm{LSD}_{0.05}$ & 366.53 & 174.69 & NS & 202.60 \\
\hline
\end{tabular}

${ }^{\mathrm{z}}$ No. 1 large ( $\geq 66 \mathrm{~mm}$ in diameter) fruit without defect.

yMean separation within columns by LSD, $P \leq 0.05$.

ssNonsignificant at $P \leq 0.05$.

$\mathrm{Ca}+\mathrm{B}$ spray, and showed a trend towards reduced shoulder check incidence, but this was not significant (Table 2). Water from the foliar spray dried rapidly on fruit and vegetative surfaces in the field, which may explain its limited impact on fruit quality (Fig. 5).

GREENHOUSE EXPERIMENT. Shoulder check defect was observed in the greenhouse experiment, but the micro-cracks were smaller in scale and primarily superficial, with limited penetration of the epidermis (Fig. 1B). In contrast, fruit had more severe shoulder check from the field experiment. The long period of high fruit moisture (caused by rain when fruit turned to mature in the field conditions) may contribute to more severe shoulder check incidence of field grown tomatoes.

Markedly similar treatment effects were observed in the greenhouse and the field environment for sprays of kaolin, $\mathrm{Ca}, \mathrm{B}$, and $\mathrm{Ca}+\mathrm{B}$. As found in the field, the high $B$ level was consistently associated with the lowest number of fruit that had defect (Fig. 6). The combined treatment of $\mathrm{Ca}$ plus $\mathrm{B}$ significantly reduced the total defect yield, as compared to water spray (Table 5), and the final cumulative number of fruit with defect (Fig.6). Weekly sprays of $\mathrm{Ca}$ at $2 \mathrm{~g} \cdot \mathrm{L}^{-1}$ and $\mathrm{Ca}+\mathrm{B}$ was consistently associated with a trend, that of increased unblemished marketable fruit (Table 5). These results agree with the other study in which combined $\mathrm{Ca}+\mathrm{B}$ sprays reduced crack formation (Dorais et al., 2001). However a reduced level (50\% lower) of $\mathrm{Ca}$ and $\mathrm{B}$ applied weekly did not influence the incidence of shoulder check in our study (Table 5).

Fig. 6. Cumulative total number of fruit shoulder with check defect and $\leq 10 \%$ number of fruit shoulder check defect for greenhouse-grown tomatoes. Treatments initiated at early fruit set in greenhouse at East Lansing, Mich., in 2001. The vertical bars represent $\mathrm{LSD}_{0.05}$ for each harvest.
Low levels of tissue B may increase the susceptibility of rapidly expanding fruit to defect occurrence. In the greenhouse environment, foliar sprays with B increased fruit tissue B levels (Table 4 and unpublished data) and, concurrently, was associated with low fruit defect incidence. Boron appears to play a role in prevention of cherry cracking through its influence on the elasticity or toughness of the plant cell wall of fruit skin (Powers and Bollen, 1947). Preharvest treatment of pear with B appears to enhance membrane integrity and reduce postharvest decay (Xuan et al., 2001). Calcium treatments were less consistent in reducing shoulder check and altering tissue $\mathrm{Ca}$ nutrition (Table 4). Calcium applied to the fruit surface may penetrate only when moisture on the fruit surface is present. Calcium nutrition has been associated in a few cases with reduced formation of macro-cracks in tomato fruit, but it is not always effective (Dickinson and McCollum, 1964).

Foliar application of kaolin was associated with a trend in the direction of reduced yield of marketable fruit and increased number of fruit with shoulder check defect (Table 5 and Fig. 6). Kaolin applied to the fruit only, rather than fruit plus foliage, had the same effect (data not shown). Water spray treatment in greenhouse showed similar trends to kaolin spray, that of increased incidence of shoulder check compared to unsprayed controls (Table 5). This
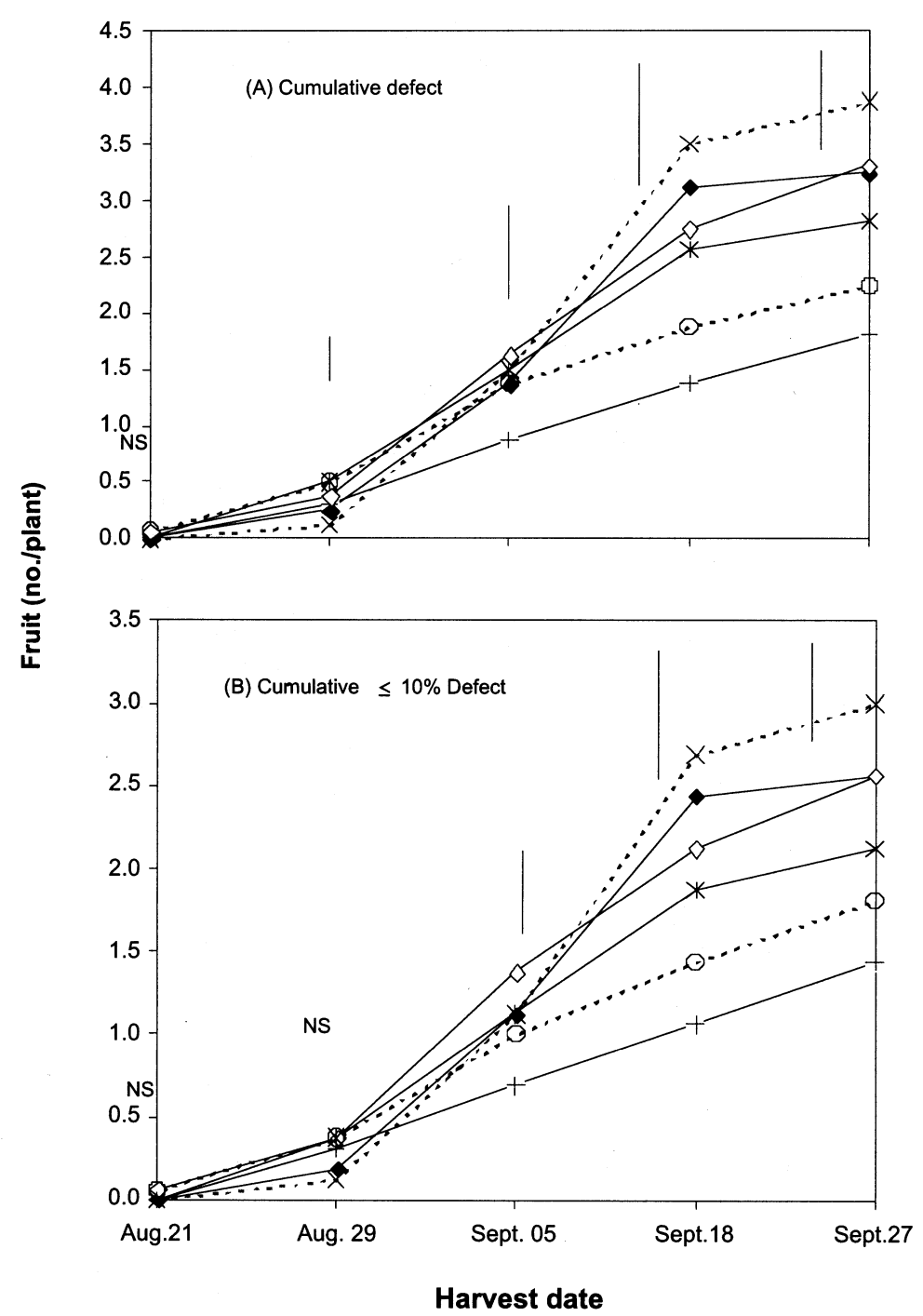

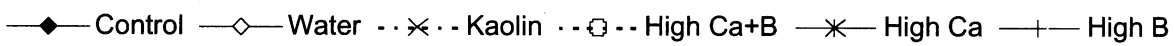


was opposite to field findings, where water spray tended (but not significantly) to be associated with an increased amount of unblemished, marketable fruit (Table 2). In the high relative humidity of the greenhouse environment, water sprayed on the fruit was slow to dry (whereas drying was rapid in the field), which may have contributed to a trend towards increased shoulder check incidence with water sprays in the greenhouse.

\section{Conclusions}

Treatment effects on the incidence of shoulder check defect were consistent across years, and at each harvest conducted. This was true despite the variability in levels of defect observed, from minor defect with $\leq 10 \%$ of fruit surface affected and superficial microcracks, to major levels of defect with microcracks that penetrated deeply through the epidermis and wound have severely reduced storability. Shoulder check occurred when fruit surface moisture changed from very low (dry conditions) to very high (wet conditions) when fruit turned to mature. Application of kaolin was consistently associated with condensation on the fruit and leaf surfaces, and concurrently with enhanced levels of defect compared to all other treatments. In contrast, the plastic cover treatment was associated with dry fruit and the lowest levels of defect, both minor and major. Plastic rain shields may not be cost-effective technologies for growers to adopt, but they do allow production of very high quality fruit.

A more practical solution may be foliar nutrition or of osmotic sprays. It appears that Ca plus B, or B alone, applied as a foliar spray provides growers with a relatively inexpensive means of providing some measure of protection against this defect. Less well understood is the role of fruit expansion rate and surface water moisture changes in initiation and expansion of micro-cracks. Further testing is underway to evaluate the role of moderate water and nutrient regimes to regulate fruit growth rate, and protect fruit quality.

\section{Literature Cited}

Bakker, J.C. 1988. Russeting (cuticle cracking) in glasshouse tomatoes in relation to fruit growth. J. Hort. Sci. 63:459-463

Brown, K. and J. Considine. 1982. Physical aspects of fruit growth. Stress distribution around lenticels. Plant Physiol. 69:585-590.

Brown, H.D. and C.V. Price. 1934. Effect of irrigation, degree of maturity, and shading upon the yield and degree of cracking of tomatoes. Proc. Amer. Soc. Hort. 32:524-528.

Considine, J. and K. Brown. 1981. Physical aspects of fruit growth. Theoretical analysis of distribution of surface growth forces in fruit in relation to cracking and splitting. Plant Physiol. 68:371-376.

Davis, J.M., D.C. Sanders, P.V. Nelson, L. Lengnick, and W.J. Sperry, 2003. Boron improves growth, yield, quality, and nutrient content of tomato. J. Amer. Soc. Hort. Sci.128:441-446.

Dickinson, D.B. and J.P. McCollum. 1964. The effect of calcium on cracking in tomato fruit. Proc. Amer. Soc. Hort. Sci. 84:485-490.

Dixon, B., G.R. Sagar, and V.M. Shorrocks. 1973. Effect of calcium and boron on the incidence of tree and storage pit in apples of the cultivar Egremont Russet. J. Hort. Sci. 48:403-411.

Dorais, M.,A.P.Papadopoulos, and A. Gosselin. 2001. Greenhouse tomato fruit quality. Hort. Rev. 26:239-319.

Ehret, D.L., T. Helmer, and J.W. Hall. 1993. Cuticle cracking in tomato fruit. J. Hort. Sci. 68:195-201

Ehret, D.L and L.C. Ho. 1986. Translocation of calcium in relation to tomato fruit growth. Ann. Bot. 58:679-688.

Emmons, C.L.W. and J.W. Scott. 1997. Environmental and physiological effects on cuticle cracking in tomato. J. Amer. Soc. Hort. Sci. 122: 797-801.
Emmons, C.L.W. and J.W. Scott. 1998. Ultrastructual and anatomical factors associated with resistance to cuticle cracking in tomato (Lycopersicon esculentum Mill.). Intl. J. Plant Sci.159:14-22.

Fernandez, R.T. and J.A. Flore. 1998. Intermittent application of $\mathrm{CaCl}_{2}$ to control rain cracking of sweet cherry. Acta Hort. 468:683-689.

Fleck, A.T. 1974. Micro determination of nitrogen. Crit. Rev. Anal. Chem. 4:141.

Francois, L.E. 1984. Effect of excess boron on tomato yield, fruit size and vegetative growth. J. Amer. Soc. Hort. Sci. 109:322-324.

Frazier, W.A. 1934. A final study of some factors associated with the occurrence of cracks in the tomato fruit. Proc. Amer. Soc. Hort. Sci.32: 519-523.

Hausbeck, M. 2002. Annual report project \#GR00-075 Reducing fruit defects affecting fresh-market tomatoes. Funded by Generating Research and Extension to meet Economic and Environmental Needs (GREEEN). Mich. State Univ. Ext., Mich. Agr. Expt. Sta., Mich. Dept. Agr. <www.greeen.msu.edu/progress2002jan/gr00075.pdf>

Hayman, G. 1987. The hair-like cracking of last season. Grower 107: 3-5.

Horwitz, W. 2000. Official methods of analysis of AOAC INTERNATIONAL (OMA). 17th ed. AOAC Intl.. Gaithersburg, Md.

Huang, J., S.S. Snapp, D. Warncke, M. Hausbeck, and B. Cortright. 2001. Possible cures for shoulder check micro-cracks in fresh-market tomatoes. Veg. Growers News 35(12):26.

Jifon, J.L. and J.P. Syvertsen 2003. Kaolin particle film applications can increase photosynthesis and water use efficiency of 'Ruby red' grapefruit leaves. J. Amer. Soc. Hort. Sci. 128:107-112

Kamimura, S., H. Yoshikawa, and K. Ito. 1972. Studies on fruit cracking in tomatoes. Bul. Hort. Res. Stat. Min. Agr. For. Ser. C (Morioka) no. 7.

Koske T.J., J.E. Pallas, and J.B. Jones. 1980. Influence of ground bed heating and cultivar on tomato fruit cracking. HortScience 15:760-762.

Nakano, A. and Y. Uehara. 1996. The effects of kaolin clay on cuticle transpiration in tomato. Acta. Hort. 440:233-238.

Palta,J.P. 1996. Role of calcium in plant responses to stresses: Linking basic research to the solution of practical problems. HortScience 31:51-57.

Peet, M.M. 1992. Radial fruit cracking in tomato. HortTechnology 2: 216-223.

Peet, M.M. and D.H. Willits. 1995. Role of excess water in tomato fruit cracking. HortScience 30:65-68.

Powers, W.L. and W.B. Bollen.1947. Control of cracking of fruit by rain. Science 105:334-335.

Shear, C.B. 1975. Calcium related disorders of fruit and vegetables. HortScience 10:361-365.

Shelp, B.J. 1993. Physiology and biochemistry of boron in plants, p. 53-85. In: U.C. Gupta (ed.).U.C. Gupta (ed.). Boron and its role in crop production. CRC Press, Boca Raton, Fla.

Simon, E.W. 1978. The symptoms of calcium deficiency in plants. New Phytol. 80:1-40.

Snapp, S.S., M. Hausbeck, D. Warncke, and R. Goldy. 2001. Update on tomato fruit quality defect 'shoulder checking'. Veg. CropAdvisory Team AlertNwsltt., Mich. State Univ.Ext. 16(16):4.http://www.msue.msu.edu/ ipm/CAT01_veg/V08-15-01.htm\#6.

Snapp, S.S., J. Huang, and D. Warncke. 2002. Improving quality of freshmarket tomato fruit. Veg. Crop Advisory Team Alert Nwsltt., Mich. State Univ. Ext. 8(16):2. http://www.msue.msu.edu/ipm/CAT02_veg/ V08-07-02.htm\#4.

Vitosh, M.L., D.D. Warncke, and R.E. Lucas. 1994. Secondary and micronutrients for vegetables and field crops. Mich. State Univ. Ext. Bul. E-486.

Xuan, H., J. Streif, H. Pfeffer, F. Dannel, V. Romheld, and F. Bangerth. 2001. Effect of preharvest boron application on the incidence of CAstorage related disorders in 'Conference' pears. J. Hort. Sci. Biotechnol. 76:133-137.

Young, P.A. 1947. Cuticle cracks in tomato fruit. Phytopathology 37:143-145. 